\title{
SATA PRIZE 1999
}

In 1997 the Governing Board of the DILA Foundation decided to devote part of an annual grant by Tokibo Ltd, Tokyo to the Foundation, for the award of a prize of US $\$ 1,500$ for an original essay of excellent quality written by a young scholar of Asian nationality on a topic of public or private international law. The prize is named after the President of Tokibo Ltd, Mr.Sata Yasuhiko.

The winning essay will be published in the Asian Yearbook of International Law. The 1999 Sata Prize will be for an essay to be published in Volume 8 (1998) of the Yearbook.

Essays must be received by the General Editors of the Yearbook not later than 31 July 1999. Each essay should be accompanied by a curriculum vitae. Participants must not be over the age of 30 years on that date. Essays must be written in English, and be of a length not less than 8,000 words and not more than 16,000 words excluding footnotes.

The Editors of the Yearbook will determine the winning essay and notify competitors of the result not later than 31 October 1999. They may also decide that none of the essays submitted is of a quality that would justify award of the prize. The decisions taken by the Editors will be final. 